Article

\title{
Carbon Nanomaterials and LED Irradiation as Antibacterial Strategies against Gram-Positive Multidrug-Resistant Pathogens
}

\author{
Lisa Elias ${ }^{1,+}$, Rafael Taengua ${ }^{2,+}$, Belén Frígols ${ }^{2,+}{ }^{\oplus}$, Beatriz Salesa ${ }^{2, \dagger}$ and \\ Ángel Serrano-Aroca $2, * \mathbb{D}$ \\ 1 Department of Biochemistry and Biotechnology, Ghent University, Krijgslaan 281, 9000 Ghent, Belgium \\ 2 Facultad de Veterinaria y Ciencias Experimentales, Universidad Católica de Valencia San Vicente Mártir, \\ c/Guillem de Castro 94, 46001 Valencia, Spain \\ * Correspondence: angel.serrano@ucv.es \\ + These authors contributed equally to this work.
}

Received: 27 June 2019; Accepted: 17 July 2019; Published: 23 July 2019

\begin{abstract}
Background: Due to current antibiotic resistance worldwide, there is an urgent need to find new alternative antibacterial approaches capable of dealing with multidrug-resistant pathogens. Most recent studies have demonstrated the antibacterial activity and non-cytotoxicity of carbon nanomaterials such as graphene oxide (GO) and carbon nanofibers (CNFs). On the other hand, light-emitting diodes (LEDs) have shown great potential in a wide range of biomedical applications. Methods: We investigated a nanotechnological strategy consisting of GO or CNFs combined with light-emitting diod (LED) irradiation as novel nanoweapons against two clinically relevant Gram-positive multidrug-resistant pathogens: methicillin-resistant Staphylococcus aureus (MRSA) and methicillin-resistant Staphylococcus epidermidis (MRSE). The cytotoxicity of GO and CNFs was studied in the presence of human keratinocyte HaCaT cells. Results: GO or CNFs exhibited no cytotoxicity and high antibacterial activity in direct contact with MRSE and MRSA cells. Furthermore, when GO or CNFs were illuminated with LED light, the MRSE and MRSA cells lost viability. The rate of decrease in colony forming units from 0 to $3 \mathrm{~h}$, measured per $\mathrm{mL}$, increased to $98.5 \pm 1.6 \%$ and $95.8 \pm 1.4 \%$ for GO and $99.5 \pm 0.6 \%$ and $99.7 \pm 0.2 \%$ for CNFs. Conclusions: This combined antimicrobial approach opens up many biomedical research opportunities and provides an enhanced strategy for the prevention and treatment of Gram-positive multidrug-resistant infections.
\end{abstract}

Keywords: carbon nanomaterials; antibacterial activity; graphene oxide; carbon nanofibers; LED; methicillin-resistant Staphylococcus aureus; methicillin-resistant Staphylococcus epidermidis; cytotoxicity; human keratinocyte HaCaT cells

\section{Introduction}

Due to the excessive use of antibiotics, hospital-associated infections are more increasingly spreading without any suitable treatment [1]. In fact, the World Health Organization has recently announced the increasing high levels of antibiotic resistance (AR) to very important pathogens [2]. Furthermore, considering the rapidly growing rate of AR in various pathogens, it is estimated that this problem could surpass all other life-threatening diseases including cancer by 2050 [3] if no proactive solutions are found to slow down the rise of drug resistance or if no alternative antibacterial strategies are successfully developed. Therefore, there is an urgent need to find new alternative non-toxic antibacterial strategies able to deal with multidrug-resistant bacteria. Thus, the most common antimicrobial strategies usually include the utilization of antibiotics [4], metal ions and 
metal oxides [5], antimicrobial peptides (AMPs) [6], $\alpha$-peptides [7], $\beta$-peptides [8], peptoids [9], and quaternary ammonium compounds (QACs) [10]. Antibiotics often show very low efficiency due to AR [11]. Metal ions and metal oxides have shown to be toxic for diverse types of mammalian cells [12]. QACs have also exhibited low efficiency due to drug resistance [13]. Peptides and peptoids are very promising but are still under industrial development [14]. However, the use of nanotechnology against multidrug-resistant pathogens has shown to be a very promising approach [15-17]. Furthermore, the antibacterial action of carbon nanomaterials is usually attributed to diverse hypotheses: membrane disruption, bacteria wrapping, electron transfer and induction of oxidative stress by reactive oxygen species. Some of these hyphotheses are based on physical mechanisms, resistances to which would be difficult for bacteria to develop $[18,19]$. Thus, carbon nanomaterials (CNMs) such as graphene oxide (GO) [20] and carbon nanofibers (CNFs) [21] have demonstrated to be a non-cytotoxic promising choice for a next-generation of antibacterial agents against clinically relevant Gram-positive pathogens [20,21]. Many studies have also confirmed the antibacterial activity of GO against Gram-negative bacterial strains [22-24] and, thus, it has been proposed as a new nanoweapon to combat multidrug-resistance bacteria [25] as a substitute to antibiotics [16]. However, the antibacterial activity and non-cytotoxicity of CNFs have recently been demonstrated under certain experimental conditions [21] and for GO, these properties are still open questions which demand further investigation because there are many controversial results. Thus, for example, GO dispersions have shown no antibacterial activity [26] and Ruiz et al. even reported that bacteria grew faster in the presence of GO because it stimulated the bacterial growth by acting as a surface to their attachment and proliferation [27]. Besides, many studies have shown that GO is toxic for some types of human cells $[28,29]$.

From the CNMs family, GO is the most utilized nanomaterial [30] because it is environmentallyfriendly and it is the easiest processing nanomaterial due to its abundant functional oxygen-containing groups, which render easier its dispersion in water. In addition, GO is now produced at a large scale and it of lower cost than other CNMs such as graphene [22]. In biomedicine, GO has shown excellent results in cancer treatment [31,32] and, in the field of antibacterial materials, silver nanoparticles (AgNPs) [33], graphene oxide-silver nanocomposites [34] and antimicrobial peptide-conjugated graphene oxide membranes [35] have shown to be powerful weapons against the multidrug-resistant bacteria methicillin-resistant Staphylococcus aureus (MRSA). However, compared with GO, carbon nanofibers (CNFs) have much more electric conductivity, which can be utilised to produce conductive composite materials [36], and a much lower cost [37]. Carbon nanofibers possess outstanding chemical, mechanical and electric properties, and present a quasi-one-dimensional morphology in the form of filaments [38,39]. Besides, we have recently reported that the addition of a minuscule amount of GO or CNFs into calcium alginate films can improve their water diffusion and compression properties significantly $[37,40]$. Other physical properties such as wettability, tensile strength and the thermal properties of hydrogels with different chemical natures have also exhibited a significant enhancement with the incorporation of CNMs [41-44].

On the other hand, light has shown to be a powerful tool to enhance bacterial killing [45]. Thus, the combination of $660 \mathrm{~nm}$ visible light together with AgNPs uniformly distributed into graphene oxide nanosheets wrapped with a thin layer of type I collagen have also shown strong antibacterial activity against Escherichia coli and Staphylococcus aureus [46]. However, the ability of bacteria to develop resistance mechanisms against $\mathrm{Ag}^{+}$[47] and the high production cost of producing pure AgNPs combined with GO limit the potential use of these strategies.

Thus, according to our previous results obtained with GO/alginate [20] and CNFs [21], in this study, we expect that these carbon nanomaterial will be able to kill two clinically relevant Gram-positive multidrug-resistant pathogens: methicillin-resistant Staphylococcus epidermidis (MRSE) and methicillin-resistant $S$. aureus (MRSA), following the same successful procedure reported by other authors for GO against the Gram-negative E. coli bacterium [24]. Furthermore, since it has recently been reported that the antibacterial activity of GO can be enhanced with simulated sunlight against $E$. coli [48] and even though Gram-positive and Gram-negative cell walls differ much, we also 
hypothesize here that the antibacterial activity of GO and CNFs against MRSE and MRSA could also be enhanced under another type of illumination, light-emitting diode (LED), which has shown to possess great potential in the biomedical field in photo rejuvenation applications, treatment of several physical abnormalities and disorders, stress relief and dentistry [49,50]. Besides, in comparison with sunlight, LED light technology shows the great advantage of being able to produce continuous light without time and weather restrictions and can be easily combined with the nanotechnology of GO and CNFs in the development of new illuminated antibacterial biomedical materials and devices.

MRSE is a multidrug-resistant bacterium spreading globally [51] and is currently one of the most important pathogens, especially among low-birth-weight premature infants [52]. S. aureus is a major human pathogen able to easily develop resistance to most antibiotics [53]. Furthermore, S. epidermidis and S. aureus currently constitute a leading cause of serious global health problems in diseases associated with medical instruments and catheters [54] due to their abundant presence on the skin of every human individual [55]. Therefore, since MRSE and MRSA are positioned between the most clinically relevant pathogens in the human skin, the cytotoxicity of CNFs and GO in contact with human keratinocyte HaCaT cells will also be analyzed in this study.

\section{Results and Discussion}

Using high-resolution transmission electron microscopy (HR-TEM), in this study, the GO and CNFs show a morphology of approximately 100-200 nm sheets (Figure 1a) and carbon nanofibers with irregular diameters of approximately $10-50 \mathrm{~nm}$ and lengths varying from some $\mathrm{nm}$ to several $\mu \mathrm{m}$ (Figure 1c) respectively.

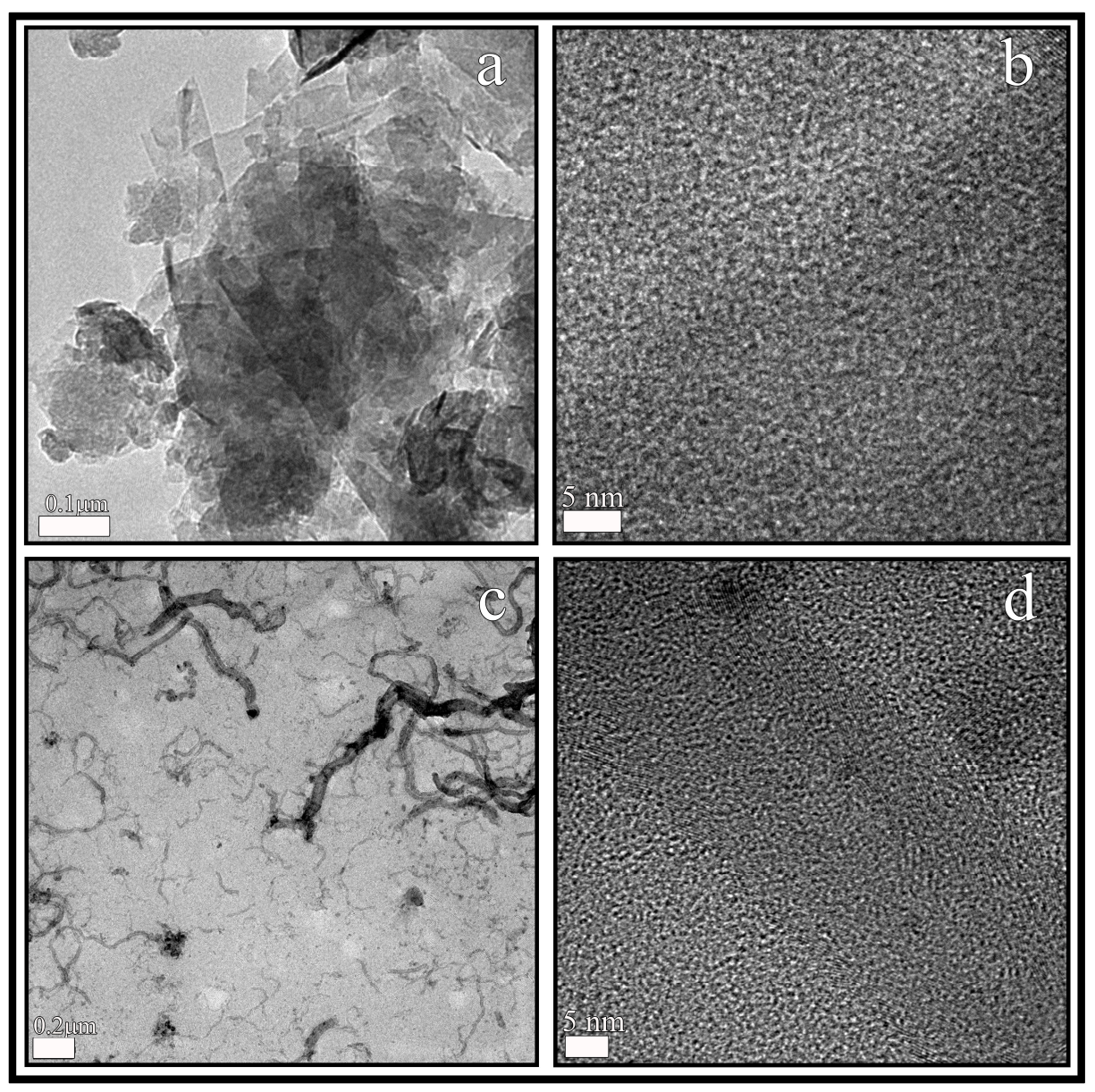

Figure 1. High-resolution transmission electron microscopy of graphene oxide nanosheets $(\mathbf{a}, \mathbf{b})$ and carbon nanofibers (c,d) at two different magnifications. 
The HR-TEM micrographs of the GO and CNFs at higher magnification both show black spots (Figure 1b,d), which were measured with the microscope's software in order to confirm $3.42 \AA$ of distance between the carbon atoms [56]. In addition, the EDS analysis showed that GO and CNFs are composed only of oxygen and carbon atoms. The carbon composition was 96.9 weight $\%(97.7$ atomic \%) for GO and 96.2 weight \% (97.2 atomic \%) for CNFs.

Raman spectroscopy is commonly utilized to obtain the structural information of CNMs $[57,58]$. Thus, the Raman spectroscopy of the GO and CNFs used in this study showed a broad D band and a strong $\mathrm{G}$ band at approximately 1330 and $1580 \mathrm{~cm}^{-1}$ respectively as expected [57,58] (Figure 2). Structural defects, edge effects and dangling $\mathrm{sp}^{2} \mathrm{C}$ bonds break symmetry in CNMs and produce a disordered band (the $\mathrm{D}$ band). The intensity ratio of the $\mathrm{D}$ and $\mathrm{G}$ bands $\left(\mathrm{I}_{\mathrm{D}} / \mathrm{I}_{\mathrm{G}}\right)$ usually measures the defect/disordered carbon structure $[59,60]$. Thus, here, the $\mathrm{I}_{\mathrm{D}} / \mathrm{I}_{\mathrm{G}}$ ratio showed a value of 0.93 typical of GO [57] and 1.49 for CNFs confirming a higher degree of disorder present in the filamentous material, typical of irregular carbon structures [58]. Moreover, the 2D band at approximately $2660 \mathrm{~cm}^{-1}$ also indicates a significant degree of disorder [58] in both the nanomaterials supporting the different chemical structure of GO and CNFs with different oxygenated functional groups randomly distributed.

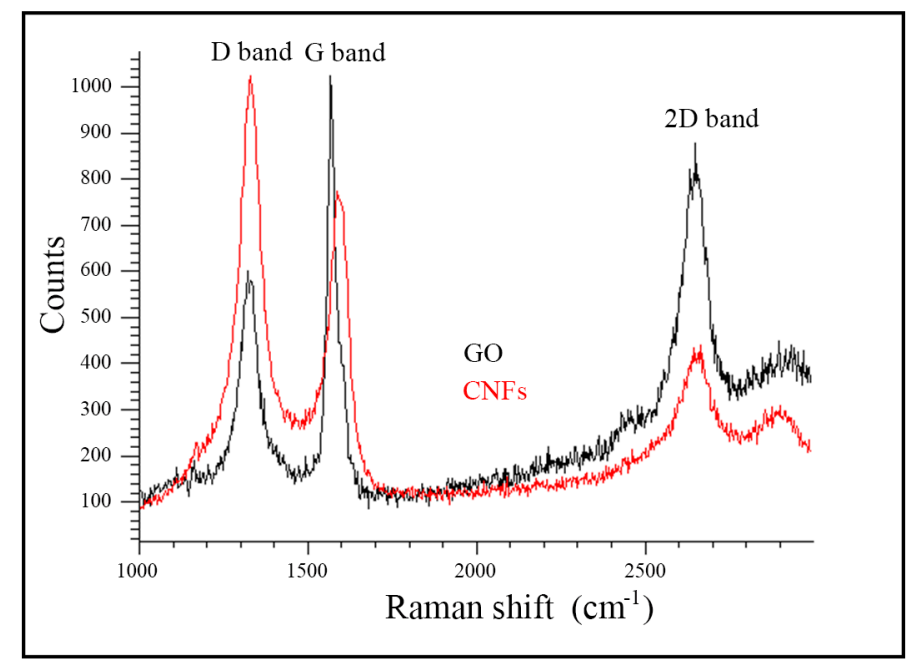

Figure 2. Raman spectrum of graphene oxide (GO) and carbon nanofibers (CNFs). The D, G and 2D bands are indicated.

The antibacterial properties of GO and CNFs against the multidrug-resistant Gram-positive MRSE and MRSA bacteria were studied by dispersing the nanomaterials in isotonic saline solution at $80 \mu \mathrm{g} / \mathrm{mL}$ to directly interact with the bacterial cells for 1.5 and $3 \mathrm{~h}$, as successfully performed previously with GO against Gram-negative E. coli [24] and CNFs against Gram-positive MRSE [21]. The results of these tests were compared with a negative control of MRSE and MRSA cells cultured without nanomaterials in isotonic saline solution and with a positive control of a well-known antibacterial agent (zinc).

Figure 3 shows that MRSE bacteria lost viability in the presence of both GO and CNFs, which were evaluated by colony counting method. The effective antibacterial activity after $3 \mathrm{~h}$ was similar to that produced by zinc. Thus, the loss of viability shown in Figure 3 occurred as a decrease in colony forming units per $\mathrm{mL}(\mathrm{CFU} / \mathrm{mL}$ ) from 0 to $3 \mathrm{~h}$. The results, using Equation (1) to calculate for exposure time in the dark, were $87.33 \pm 12.12 \%$ for GO, $95.68 \pm 3.58 \%$ for CNFs and $96.74 \pm 3.79 \%$ for zinc.

$$
L V(\%)=\frac{C_{0}-C}{C_{0}} \times 100
$$




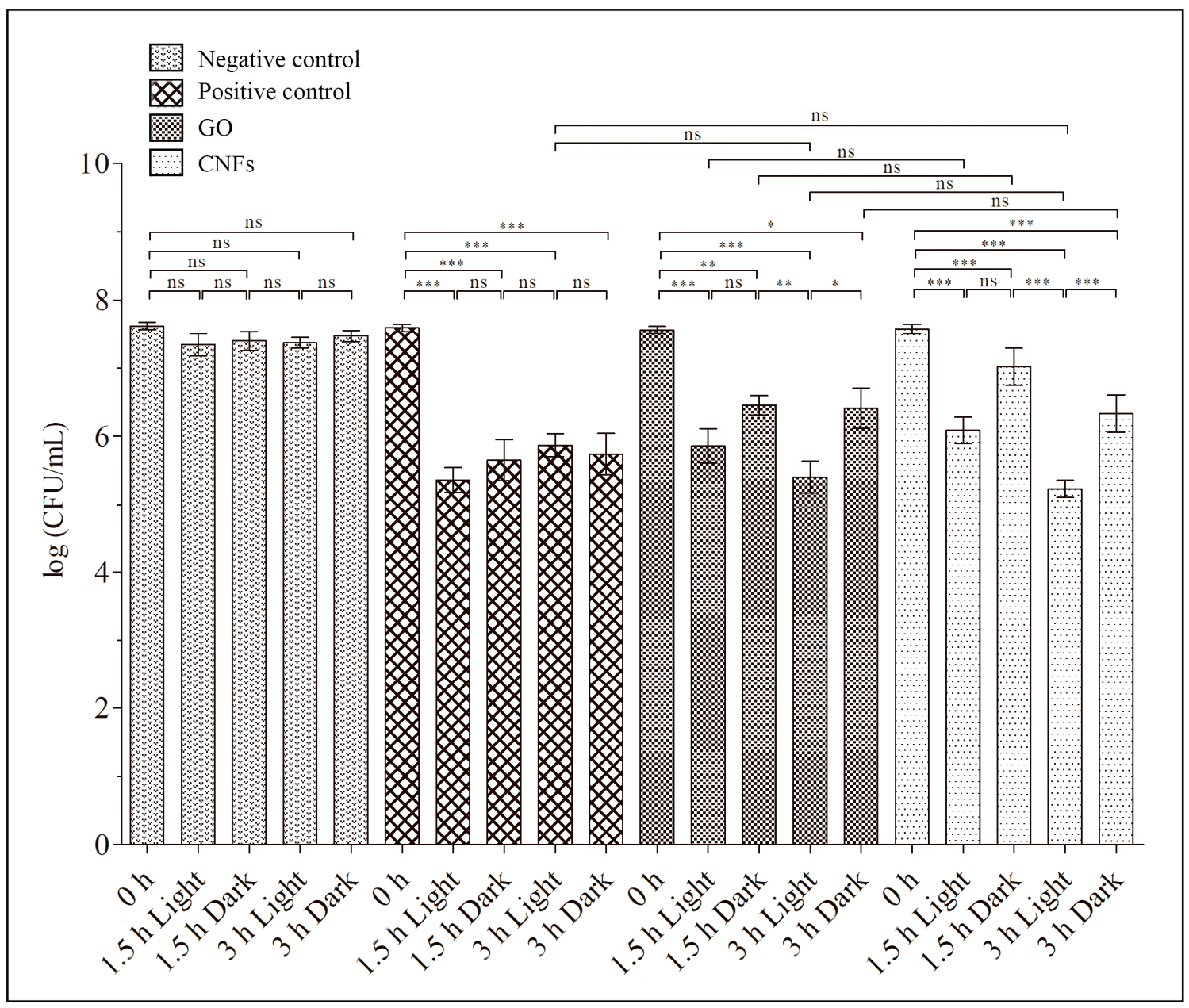

Figure 3. Methicillin-resistant Staphylococcus epidermidis (MRSE) cultured in isotonic saline solution (negative control), and in isotonic saline solution with $80 \mu \mathrm{g} / \mathrm{mL}$ of graphene oxide (GO), carbon nanofibers (CNFs) or zinc (positive control) at time zero and after 1.5 and $3 \mathrm{~h}$ of culture at $37^{\circ} \mathrm{C}$ in the dark and under continuous LED irradiation. Error bars represent standard deviation. The ANOVA results are indicated in this plot. ${ }^{*} p>0.05 ;{ }^{* *} p>0.01 ;{ }^{* * *} p>0.001$; ns: not significant.

Furthermore, Figure 3 shows the significant enhancement of antibacterial activity when combining GO nanosheets or CNFs with LED irradiation after 3 hours. However, no statistically significant differences of antibacterial activity were observed between both CNMs in terms of a decrease in $\mathrm{CFU} / \mathrm{mL}$. Thus, the loss of viability of the MRSE cells, determined from the decrease in CFU $/ \mathrm{mL}$ from time 0 to $3 \mathrm{~h}$ by applying Equation (1), was $98.5 \pm 1.6 \%$ and $99.5 \pm 0.6 \%$ for the GO and CNFs, respectively, under continuous LED light.

The negative control samples were cultured in isotonic saline solution for $3 \mathrm{~h}$. Thus, a slight decrease or no increase in bacterial viability of the negative controls was expected due to the lack of nutrients. No effect of LED irradiation was observed for the negative or positive controls.

Figure 4 shows representative plate photographs of the antibacterial tests for both nanomaterials and control cultures with MRSE at $0 \mathrm{~h}$ and after 1.5 and $3 \mathrm{~h}$ of culture at $37^{\circ} \mathrm{C}$. 


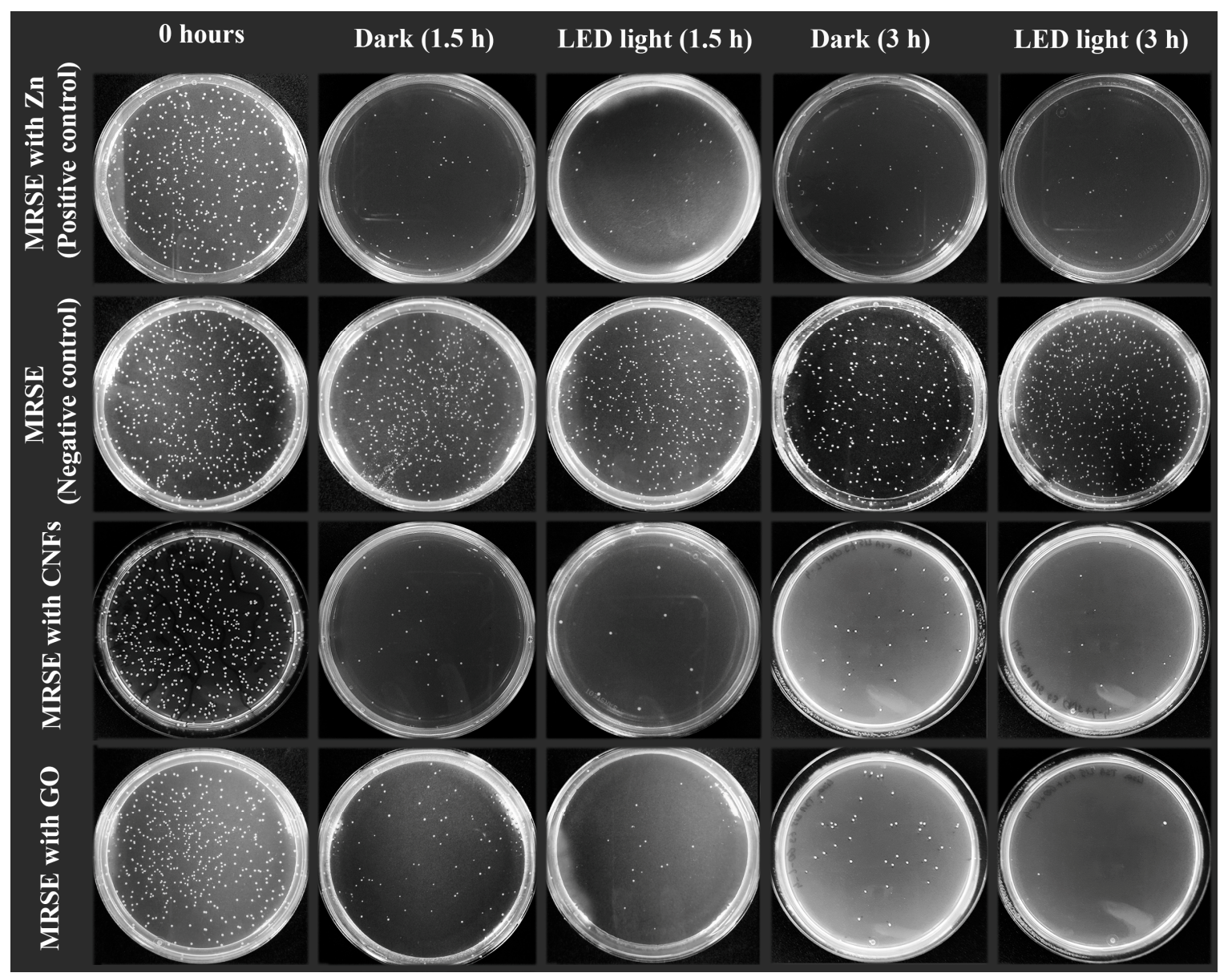

Figure 4. Representative plate photographs of the colony forming units (CFUs) for the antibacterial tests performed with methicillin-resistant Staphylococcus epidermidis (MRSE) in isotonic saline solution (negative control), and in isotonic saline solution with $80 \mu \mathrm{g} / \mathrm{mL}$ of graphene oxide (GO), carbon nanofibers (CNFs) or zinc (positive control) after 1.5 and $3 \mathrm{~h}$ of culture at $37^{\circ} \mathrm{C}$ in the dark and under continuous LED irradiation (Dilution factor of $10^{-4}$ ).

The loss of viability of the other Gram-positive multidrug-resistant strain, MRSA, in the presence of GO or CNFs, evaluated by the colony counting method, also exhibited effective antibacterial activity after $3 \mathrm{~h}$ in a similar way to that produced by zinc (Figure 5). Thus, the loss of viability, using Equation (1) to calculate for exposure time in the dark, was $87.05 \pm 7.75 \%$ for GO, $91.22 \pm 3.53 \%$ for CNFs and $87.35 \pm 6.41 \%$ for zinc.

These results also show the significant enhancement of antibacterial activity when these CNMs were illuminated with a LED light lamp after $3 \mathrm{~h}$. In addition, LED irradiation statistically showed more effect in combination with the filamentous CNFs than with GO nanosheets against MRSA in terms of a decrease in the logarithm of CFU per $\mathrm{mL}$ for both culture times (1.5 and $3 \mathrm{~h}$ ). Thus, the loss of viability of the MRSA cells, calculated from the results shown in Figure 5 as the decrease in CFU/mL from time 0 to 1.5 and $3 \mathrm{~h}$, by applying Equation (1), showed that MRSA cultivated in isotonic saline solution with GO or CNFs in combination with continuous LED illumination was $66.1 \pm 8.1 \%$ and $87.1 \pm 4.5 \%$, respectively for $1.5 \mathrm{~h}$ and $95.8 \pm 1.4 \%$ and $99.7 \pm 0.2 \%$ respectively for $3 \mathrm{~h}$. This slight increase in antibacterial activity could be attributed to the fact that filamentous carbon nanomaterials possess a larger surface area [61] exposed to the LED irradiation than graphene oxide nanosheets. However, the greater effect of LED light on CNFs than on GO was not observed with the other multidrug-resistant strain (Figure 3). 


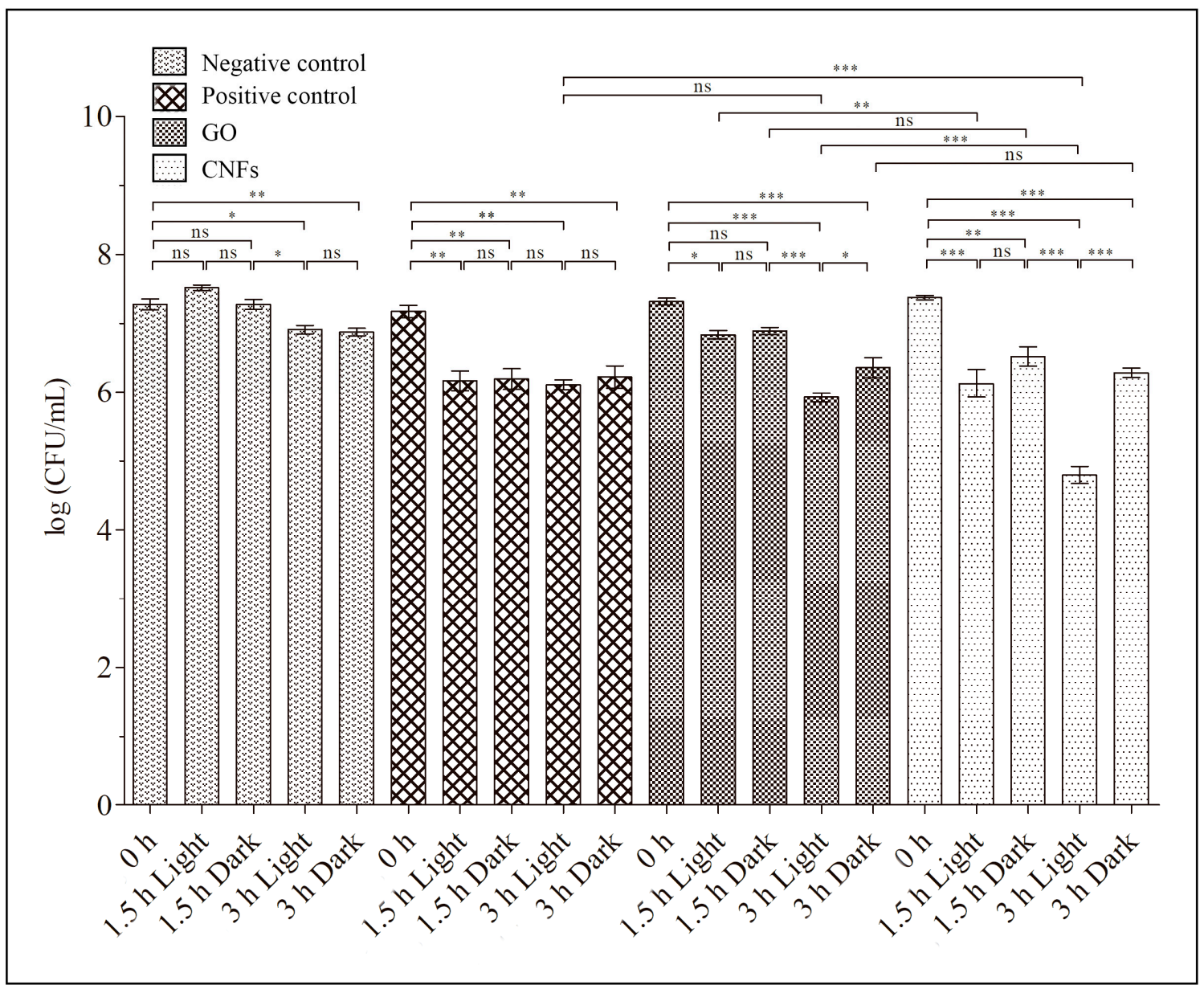

Figure 5. Methicillin-resistant Staphylococcus aureus (MRSA) cultured in isotonic saline solution (negative control), and in isotonic saline solution with $80 \mu \mathrm{g} / \mathrm{mL}$ of graphene oxide (GO), carbon nanofibers (CNFs) or zinc (positive control) at time zero and after 1.5 and $3 \mathrm{~h}$ of culture at $37^{\circ} \mathrm{C}$ in the dark and under continuous LED irradiation. Error bars represent standard deviation. The ANOVA results are indicated in this plot. ${ }^{*} p>0.05 ;{ }^{* *} p>0.01 ;{ }^{* * *} p>0.001$; ns: not significant.

The negative control samples were cultured in isotonic saline solution for $3 \mathrm{~h}$. Thus, a slight decrease or no growth of bacterial viability of the negative controls was expected due to the lack of nutrients. No effect of LED irradiation was observed for the negative or positive controls.

All these results are in good agreement with those previously published for GO against Gram-negative E. coli for the same experimental conditions (concentration and time exposures) [24].

Figure 6 shows representative plate photographs of the antibacterial tests for the CNMs dispersed in isotonic saline solution at $80 \mu \mathrm{g} / \mathrm{mL}$ in direct contact with the MRSA cells after 1.5 and $3 \mathrm{~h}$ of culture at $37^{\circ} \mathrm{C}$ in the dark and under continuous LED illumination. 


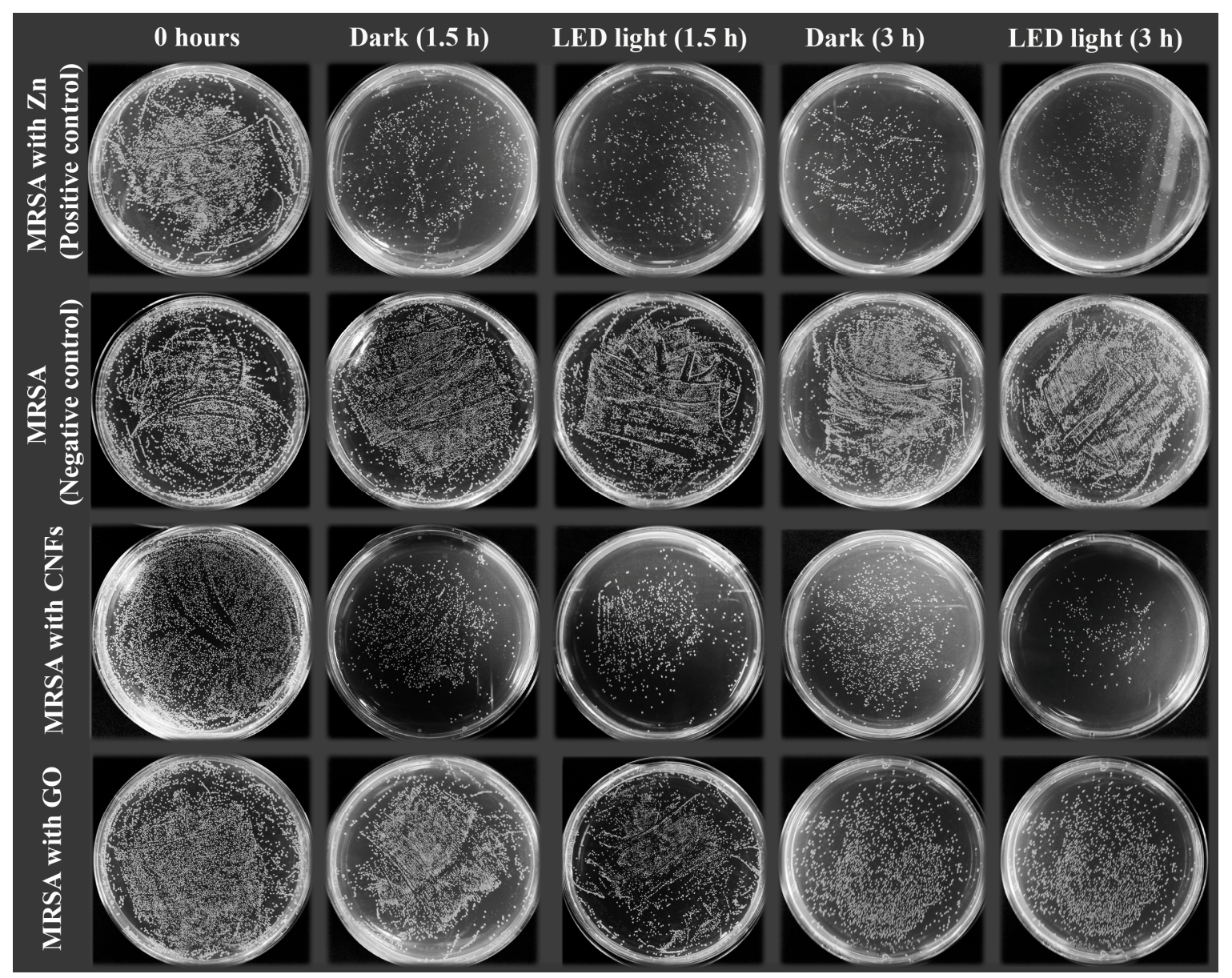

Figure 6. Representative plate photographs of the colony forming units (CFUs) for the antibacterial tests performed with methicillin-resistant Staphylococcus aureus (MRSA) in isotonic saline solution (negative control), and in isotonic saline solution with $80 \mu \mathrm{g} / \mathrm{mL}$ of graphene oxide (GO), carbon nanofibers (CNFs) or zinc (positive control) after 1.5 and $3 \mathrm{~h}$ of culture at $37^{\circ} \mathrm{C}$ in the dark and under continuous LED irradiation (Dilution factor of $10^{-2}$ ).

Finally, the methylthiazolydiphenyl-tetrazolium bromide (MTT) assays of the CNMs showed no statistically significant cytotoxicity in the presence of human keratinocyte $\mathrm{HaCaT}$ cells for $3 \mathrm{~h}$ of culture at $37^{\circ} \mathrm{C}$ (Figure 7).

These results confirm our hypotheses that the antibacterial activity of GO and CNFs can be enhanced under continuous LED light against the Gram-positive multidrug-resistant MRSE and MRSA pathogens. LED irradiation must accelerate the electron transfer from antioxidant biomolecules to the CNMs, which simultaneously destroys bacterial antioxidant systems and produces the reduction of the CNMs as reported upon exposure to simulated sunlight on GO [48]. The successful results obtained against E. coli with simulated sunlight, and, here against MRSE and MRSA with LED irradiation, broaden the specificity of this antibacterial strategy.

The relatively long treatment period $(1.5$ or $3 \mathrm{~h}$ ) of these combined nanotechnologies could limit their utility for surface or device disinfection. However, these results open up new exciting opportunities for potential clinical application where LED light technology can be utilized in combination with the nanotechnology of GO or CNFs as novel antibacterial nanoweapons for the prevention and treatment of Gram-positive multidrug-resistant infections. 


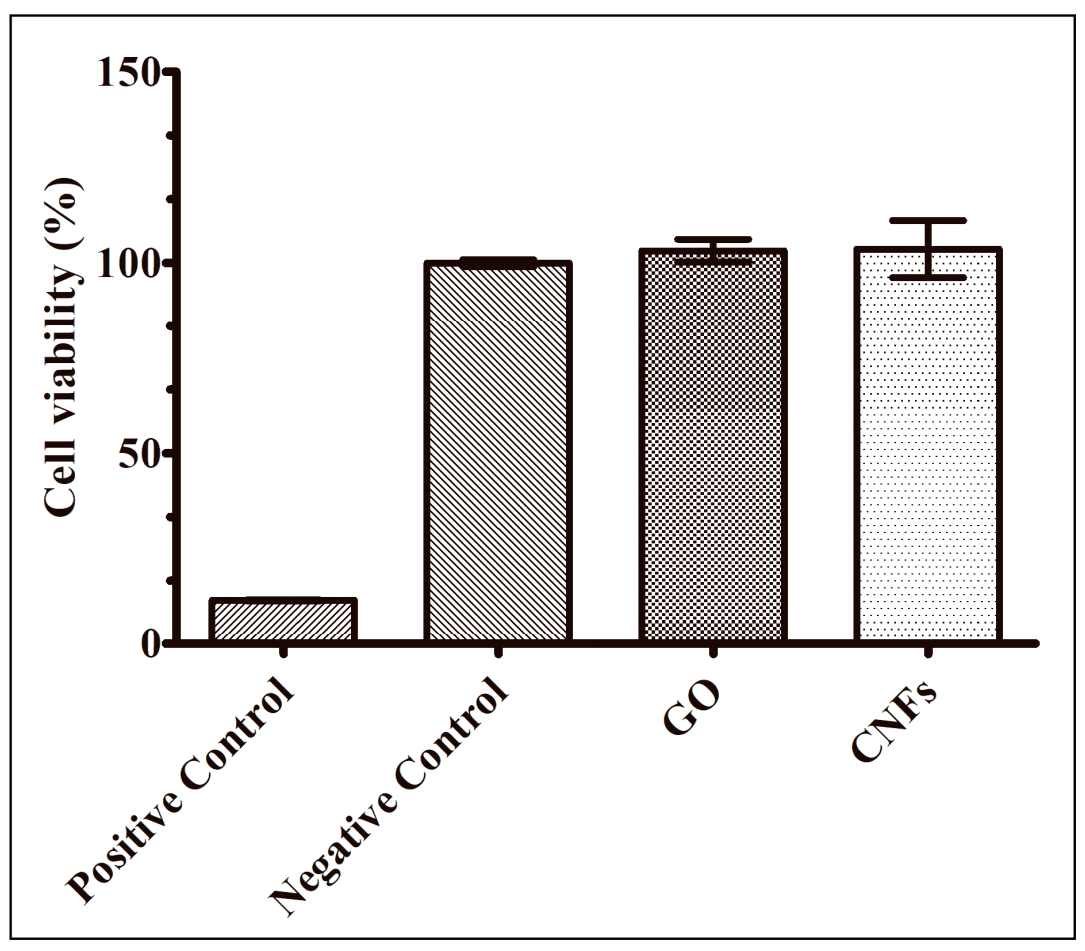

Figure 7. Cytotoxicity results (MTT assay) for graphene oxide (GO) and carbon nanofibers (CNFs) dispersed in isotonic saline solutions, isotonic saline solution with zinc (positive control) and isotonic saline solution (negative control) in the presence of human keratinocyte $\mathrm{HaCaT}$ cells at $37^{\circ} \mathrm{C}$ for $3 \mathrm{~h}$. No statistically significant $(p<0.01)$ differences of cell viability were found between the negative control and GO or CNF sample cultures.

\section{Materials and Methods}

\subsection{Carbon Nanomaterials}

Graphene oxide powder (GO, 15-20 sheets, 4-10\% edge-oxidized, Sigma-Aldrich, St. Louis, MO, USA) and carbon nanofibers (CNFs, Graphenano, Yecla, Spain) were used as received.

\subsection{Electron Microscopy}

GO nanosheets and carbon nanofibers were observed in a JEM 2100F $200 \mathrm{kV}$ high-resolution transmission electron microscope (HR-TEM, JEOL, Tokyo, Japan). This equipment is provided with energy-disperse X-ray spectroscopy (EDS) to determine elemental compositions at $20 \mathrm{kV}$. The carbon nanomaterials were ultrasonically dispersed in dichloromethane for $10 \mathrm{~min}$ and after that, they were dried at ambient temperature before HR-TEM observation.

\subsection{Raman Spectroscopy}

Raman spectroscopy was performed from 1000 to $3000 \mathrm{~cm}^{-1}$ in a Renishaw inVia confocal micro-Raman spectrometer using an argon ion laser at $633 \mathrm{~nm}$ and $\times 20$ lens at $600 \mathrm{~L} \cdot \mathrm{mm}^{-1} \mathrm{grating}^{-}$ The GO or CNFs powder was deposited onto a glass disk for direct observation.

\subsection{Antibacterial Test}

Graphene oxide exhibited significant antibacterial action against Gram-negative E. coli bacterium, at $80 \mu \mathrm{g} / \mathrm{mL}$, dispersed in isotonic saline solution (to remove chemical interactions with medium compounds) and $3 \mathrm{~h}$ of direct contact [24]. Therefore, according to the procedure described in that work, sterile samples of GO or CNFs dispersed in isotonic saline solution $(\mathrm{NaCl} 0.9 \% w / v)$, from FisioVet (B. Braun VetCare SA, Barcelona, Spain) at the same concentration $(80 \mu \mathrm{g} / \mathrm{mL})$, and autoclaved 
at $121^{\circ} \mathrm{C}$ for $15 \mathrm{~min}$, were prepared by sonication for two hours right before being used for the bacterial cultures. The methicillin-resistant Staphylococcus epidermidis, RP62A [62], and the methicillin-resistant Staphylococcus aureus, COL [63], Gram-positive bacterial strains were utilized for the antibacterial tests. Thus, bacterial cultures were used in TSB in a shaking incubator $\left(140 \mathrm{rpm}\right.$ and $\left.37^{\circ} \mathrm{C}\right)$ overnight. Cell samples of $10^{6}$ to $10^{7} \mathrm{CFU} / \mathrm{mL}$ were prepared by dilution of these cultures and harvestation in the mid-exponential growth phase. Bacterial concentrations were determined with a Nanocolor UV0245 UV/VIS spectrophotometer (Macherey-Nagel, Düren, Germany) at $540 \mathrm{~nm}$. In order to pellet cells, the cultures were centrifuged at $6000 \mathrm{rpm}(3952 \times \mathrm{g})$ for $10 \mathrm{~min}$. After centrifugation, cells were washed with isotonic saline solution three times to ensure complete elimination of any type of residual molecules such as growth medium compounds. The bacterial cells were then resuspended in fresh sterile GO dispersion to be incubated at $37^{\circ} \mathrm{C}$ under $250 \mathrm{rpm}$ shaking speed for 1.5 and $3 \mathrm{~h}$. The loss of viability of the microorganisms was evaluated by the colony counting method [64] after those two selected times. Thus, $100 \mu \mathrm{L}$ of each cell dilution was spread onto TSA plates and left to grow overnight at $37^{\circ} \mathrm{C}$. Colonies were counted and compared with those grown on negative control plates, which were obtained from the control bacterial cultures without GO or CNFs. Furthermore, a positive control culture was used with a well-known antibacterial agent (zinc [65]). In this positive control, zinc chloride ( $\geq 97.0 \%$, Sigma-Aldrich) was dissolved in isotonic saline solution to a concentration of $80 \mu \mathrm{g} / \mathrm{mL}$. The microorganism cultures were placed in $15 \mathrm{~mL}$ transparent tubes placed, in the vertical position in the dark (covered with aluminum foil) and under continuous light using a 50W 4000 lumens LED lamp (F-Bright Led, Bizkaia, Loiu, Spain) with Daylight White 6000K Color and $285 \times 54$ $\times 240 \mathrm{~mm}$ dimensions, located at a distance of $34.7 \mathrm{~cm}$ from the culture on the top of a transparent Certomat IS orbital shaking incubator (Sartorius Stedim Biotech, Göttingen, Germany) at $37^{\circ} \mathrm{C}$ for $3 \mathrm{~h}$. The amount of light at this distance was 10710 Lux, which was measured with a DVM1300 Velleman light meter (Velleman, Inc., Fort Worth, TX, USA).

Loss of viability $(L V)$ can be determined as the decrease in CFU/mL from time zero $\left(C_{0}\right)$ to 1.5 or $3 \mathrm{~h}$ of culture $(C)$ divided by the initial concentration $\left(C_{0}\right)$ as expressed in Equation (1) [24].

These antibacterial tests were performed in triplicate in three different days $(n=9)$ to provide reproducibility.

\subsection{MTT Cytotoxicity Assay for GO and CNFs}

Human keratinocyte HaCaT cells were provided by the Medical Research Institute Hospital La $\mathrm{Fe}$ (Valencia, Spain) for the cytotoxicity assays. The cell viability of these human cells was evaluated in the presence of GO or CNFs by the methylthiazolyldiphenyl-tetrazolium bromide (MTT) test. Cell culture was performed in a 96-well plate at a density of $5 \times 10^{5}$ cells/well. After 24 hours of incubation, the culture medium of each well was replaced with $100 \mu \mathrm{L}$ dispersions of GO or CNFs into isotonic saline solution at the same concentration that was used for the antibacterial tests $(80 \mu \mathrm{g} / \mathrm{mL})$. The dispersion of the nanomaterials was produced by $2 \mathrm{~h}$ sonication and always used immediately. $100 \mu \mathrm{L}$ of pure isotonic saline solution (without GO or CNFs) and $100 \mu \mathrm{L}$ of isotonic saline solution with a high concentration of zinc $(1000 \mu \mathrm{M})$, that is over the toxicity level for mammalian cells [66], were also used to replace the culture medium as negative and positive controls, respectively. After $3 \mathrm{~h}$ of incubation (maximum time exposure in the antibacterial assays), the cells were incubated with 5 $\mathrm{mg} / \mathrm{mL}$ MTT in each well for $4 \mathrm{~h}$. Finally, the formazan was dissolved in $100 \mu \mathrm{L}$ of dimethyl sulfoxide at $24 \pm 1{ }^{\circ} \mathrm{C}$ and absorbance readings were carried out at $550 \mathrm{~nm}$ on a microplate reader (Varioskan, Thermo Fisher, Waltham, MA, USA).

\subsection{Statistical Analysis}

The results obtained in this study were statistically analyzed by ANOVA followed by multiple Tukey's post-hoc analysis using the GraphPad Prism 6 software (San Diego, CA, USA) at significance level of at a least $p<0.05$. 


\section{Conclusions}

This study has shown that graphene oxide nanosheets and carbon nanofibers are valuable antibacterial carbon nanomaterials able to kill two clinically relevant Gram-positive multidrug-resistant strains: methicillin-resistant Staphylococcus epidermidis and methicillin-resistant Staphylococcus aureus. Furthermore, LED light technology was shown to be able to significantly enhance the antibacterial properties of graphene oxide nanosheets and carbon nanofibers against these life-threatening pathogens. Therefore, these carbon nanomaterials in combination with LED irradiation for $3 \mathrm{~h}$ periods had an efficient antibacterial effect against MRSE and MRSA pathogens. The implementation of these combined technologies opens up a wide range of research opportunities in many important fields within the biomedical and bioengineering sector.

Author Contributions: Investigation: L.E., R.T., B.F., B.S., Á.S.-A.; Methodology, validation and resources: B.F., B.S., Á.S.-A.; Supervision: B.F., Á.S.-A.; Conceptualization, software, formal analysis, data curation, visualization, project administration, funding acquisition, writing-original draft preparation, writing-review \& editing: Á.S.-A.

Funding: Financial support through the 2018-231-001UCV and 2019-231-003UCV grants (awarded to Á.S-A) from the Universidad Católica de Valencia San Vicente Mártir.

Acknowledgments: The authors would also like to acknowledge the Universidad Católica de Valencia San Vicente Mártir for the financial support.

Conflicts of Interest: The authors declare no conflict of interest.

\section{Abbreviations}

$\begin{array}{ll}\text { LED } & \text { Light-emitting diode } \\ \text { GO } & \text { Graphene oxide } \\ \text { CNFs } & \text { Carbon nanofibers } \\ \text { CNMs } & \text { Carbon nanomaterials } \\ \text { MRSA } & \text { Methicillin-resistant Staphylococcus aureus } \\ \text { MRSE } & \text { Methicillin-resistant Staphylococcus epidermidis } \\ \text { AR } & \text { Antibiotic resistance } \\ \text { AMPs } & \text { Antimicrobial peptides } \\ \text { HR-TEM } & \text { High-resolution transmission electron microscopy } \\ \text { EDS } & \text { Energy-disperse X-ray spectroscopy } \\ \text { CFUs } & \text { Colony-forming units } \\ \text { QAC } & \text { Quaternary ammonium compounds } \\ \text { AgNPs } & \text { Silver nanoparticles } \\ \text { LV } & \text { Loss of viability }\end{array}$

\section{References}

1. Fernández, J.; Bert, F.; Nicolas-Chanoine, M.H. The challenges of multi-drug-resistance in hepatology. J. Hepatol. 2016, 65, 1043-1054. [CrossRef] [PubMed]

2. WHO. High Levels of Antibiotic Resistance Found Worldwide, New Data Shows. Available online: http://www.who.int/mediacentre/news/releases/2018/antibiotic-resistance-found/en/ (accessed on 22 July 2019).

3. O'neill, J. Tackling Drug-Resistant Infections Globally: Final Report and Recommendations. In The Review on Antimicrobial Resistance; Wellcome Trust and HM Government: London, UK, 2016.

4. Pandey, H.; Parashar, V.; Parashar, R.; Prakash, R.; Ramteke, P.W.; Pandey, A.C. Controlled drug release characteristics and enhanced antibacterial effect of graphene nanosheets containing gentamicin sulfate. Nanoscale 2011, 3, 4104-4108. [CrossRef] [PubMed]

5. Liu, Y.; Wang, X.; Yang, F.; Yang, X. Excellent antimicrobial properties of mesoporous anatase $\mathrm{TiO}_{2}$ and $\mathrm{Ag} / \mathrm{TiO}_{2}$ composite films. Microporous Mesoporous Mater. 2008, 114, 431-439. [CrossRef]

6. Wang, L.; Chen, J.; Shi, L.; Shi, Z.; Ren, L.; Wang, Y. The promotion of antimicrobial activity on silicon substrates using a "click" immobilized short peptide. Chem. Commun. 2014, 50, 975-977. [CrossRef] [PubMed] 
7. Chen, Y.; Mant, C.T.; Farmer, S.W.; Hancock, R.E.W.; Vasil, M.L.; Hodges, R.S. Rational design of alpha-helical antimicrobial peptides with enhanced activities and specificity/therapeutic index. J. Biol. Chem. 2005, 280, 12316-12329. [CrossRef] [PubMed]

8. Porter, E.A.; Wang, X.; Lee, H.S.; Weisblum, B.; Gellman, S.H. Non-haemolytic beta-amino-acid oligomers. Nature 2000, 404, 565. [CrossRef] [PubMed]

9. Chongsiriwatana, N.P.; Patch, J.A.; Czyzewski, A.M.; Dohm, M.T.; Ivankin, A.; Gidalevitz, D.; Zuckermann, R.N.; Barron, A.E. Peptoids that mimic the structure, function, and mechanism of helical antimicrobial peptides. Proc. Natl. Acad. Sci. USA 2008, 105, 2794-2799. [CrossRef] [PubMed]

10. Jia, Z.; Shen, D.; Xu, W. Synthesis and antibacterial activities of quaternary ammonium salt of chitosan. Carbohydr. Res. 2001, 333, 1-6. [CrossRef]

11. Ng, V.W.L.; Chan, J.M.W.; Sardon, H.; Ono, R.J.; García, J.M.; Yang, Y.Y.; Hedrick, J.L. Antimicrobial hydrogels: A new weapon in the arsenal against multidrug-resistant infections. Adv. Drug Deliv. Rev. 2014, 78, 46-62. [CrossRef]

12. Ahamed, M.; AlSalhi, M.S.; Siddiqui, M.K.J. Silver nanoparticle applications and human health. Clin. Chim. Acta 2010, 411, 1841-1848. [CrossRef]

13. Hegstad, K.; Langsrud, S.; Lunestad, B.T.; Scheie, A.A.; Sunde, M.; Yazdankhah, S.P. Does the Wide Use of Quaternary Ammonium Compounds Enhance the Selection and Spread of Antimicrobial Resistance and Thus Threaten Our Health? Microb. Drug Resist. 2010, 16, 91-104. [CrossRef] [PubMed]

14. McLean, D.T.F.; Lundy, F.T.; Timson, D.J. IQ-motif peptides as novel anti-microbial agents. Biochimie 2013, 95, 875-880. [CrossRef] [PubMed]

15. Pelgrift, R.Y.; Friedman, A.J. Nanotechnology as a therapeutic tool to combat microbial resistance. Adv. Drug Deliv. Rev. 2013, 65, 1803-1815. [CrossRef] [PubMed]

16. Seil, J.T.; Webster, T.J. Antimicrobial applications of nanotechnology: Methods and literature. Int. J. Nanomed. 2012, 7, 2767-2781.

17. Blecher, K.; Nasir, A.; Friedman, A. The growing role of nanotechnology in combating infectious disease. Virulence 2011, 2, 395-401. [CrossRef] [PubMed]

18. Zou, X.; Zhang, L.; Wang, Z.; Luo, Y. Mechanisms of the Antimicrobial Activities of Graphene Materials. J. Am. Chem. Soc. 2016, 138, 2064-2077. [CrossRef] [PubMed]

19. Tegou, E.; Magana, M.; Katsogridaki, A.E.; Ioannidis, A.; Raptis, V.; Jordan, S.; Chatzipanagiotou, S.; Chatzandroulis, S.; Ornelas, C.; Tegos, G.P. Terms of endearment: Bacteria meet graphene nanosurfaces. Biomaterials 2016, 89, 38-55. [CrossRef]

20. Martí, M.; Frígols, B.; Salesa, B.; Serrano-Aroca, Á. Calcium alginate/graphene oxide films: Reinforced composites able to prevent Staphylococcus aureus and methicillin-resistant Staphylococcus epidermidis infections with no cytotoxicity for human keratinocyte HaCaT cells. Eur. Polym. J. 2018, in press. [CrossRef]

21. Salesa, B.; Martí, M.; Frígols, B.; Serrano-Aroca, Á. Carbon Nanofibers in Pure Form and in Calcium Alginate Composites Films: New Cost-Effective Antibacterial Biomaterials against the Life-Threatening Multidrug-Resistant Staphylococcus epidermidis. Polymers 2019, 11, 453. [CrossRef]

22. Papi, M.; Palmieri, V.; Bugli, F.; De Spirito, M.; Sanguinetti, M.; Ciancico, C.; Braidotti, M.C.; Gentilini, S.; Angelani, L.; Conti, C. Biomimetic antimicrobial cloak by graphene-oxide agar hydrogel. Sci. Rep. 2016, 6, 12. [CrossRef]

23. Santos, C.M.; Tria, M.C.R.; Vergara, R.A.M.V.; Ahmed, F.; Advincula, R.C.; Rodrigues, D.F. Antimicrobial graphene polymer (PVK-GO) nanocomposite films. Chem. Commun. 2011, 47, 8892-8894. [CrossRef] [PubMed]

24. Liu, S.; Zeng, T.H.; Hofmann, M.; Burcombe, E.; Wei, J.; Jiang, R.; Chen, Y. Antibacterial activity of graphite, graphite oxide, graphene oxide, and reduced graphene oxide: Membrane and oxidative stress. ACS Nano 2011, 5, 6971-6980. [CrossRef] [PubMed]

25. Yousefi, M.; Dadashpour, M.; Hejazi, M.; Hasanzadeh, M.; Behnam, B.; de la Guardia, M.; Shadjou, N.; Mokhtarzadeh, A. Anti-bacterial activity of graphene oxide as a new weapon nanomaterial to combat multidrug-resistance bacteria. Mater. Sci. Eng. C 2017, 74, 568-581. [CrossRef] [PubMed]

26. De Faria, A.F.; Martinez, D.S.T.; Meira, S.M.M.; de Moraes, A.C.M.; Brandelli, A.; Filho, A.G.S.; Alves, O.L. Anti-adhesion and antibacterial activity of silver nanoparticles supported on graphene oxide sheets. Colloids Surf. B Biointerfaces 2014, 113, 115-124. [CrossRef] [PubMed] 
27. Ruiz, O.N.; Fernando, K.A.S.; Wang, B.; Brown, N.A.; Luo, P.G.; McNamara, N.D.; Vangsness, M.; Sun, Y.P.; Bunker, C.E. Graphene oxide: A nonspecific enhancer of cellular growth. ACS Nano 2011, 5, 8100-8107. [CrossRef] [PubMed]

28. Vallabani, N.V.S.; Mittal, S.; Shukla, R.K.; Pandey, A.K.; Dhakate, S.R.; Pasricha, R.; Dhawan, A. Toxicity of graphene in normal human lung cells (BEAS-2B). J. Biomed. Nanotechnol. 2011, 7, 106-107. [CrossRef] [PubMed]

29. Zhang, W.; Yan, L.; Li, M.; Zhao, R.; Yang, X.; Ji, T.; Gu, Z.; Yin, J.J.; Gao, X.; Nie, G. Deciphering the underlying mechanisms of oxidation-state dependent cytotoxicity of graphene oxide on mammalian cells. Toxicol. Lett. 2015, 237, 61-71. [CrossRef] [PubMed]

30. Perreault, F.; Tousley, M.E.; Elimelech, M. Thin-Film Composite Polyamide Membranes Functionalized with Biocidal Graphene Oxide Nanosheets. Environ. Sci. Technol. Lett. 2013, 1,71-76. [CrossRef]

31. Fiorillo, M.; Verre, A.F.; Iliut, M.; Peiris-Pagés, M.; Ozsvari, B.; Gandara, R.; Cappello, A.R.; Sotgia, F.; Vijayaraghavan, A.; Lisanti, M.P. Graphene oxide selectively targets cancer stem cells, across multiple tumor types: Implications for non-toxic cancer treatment, via "differentiation-based nano-therapy". Oncotarget 2015, 6, 3553-3562. [CrossRef]

32. Gurunathan, S.; Kang, M.H.; Qasim, M.; Kim, J.H. Nanoparticle-mediated combination therapy: Two-in-one approach for cancer. Int. J. Mol. Sci. 2018, 19, 3264. [CrossRef]

33. Rai, M.K.; Deshmukh, S.D.; Ingle, A.P.; Gade, A.K. Silver nanoparticles: The powerful nanoweapon against multidrug-resistant bacteria. J. Appl. Microbiol. 2012, 112, 841-852. [CrossRef]

34. De Moraes, A.C.M.; Lima, B.A.; de Faria, A.F.; Brocchi, M.; Alves, O.L. Graphene oxide-silver nanocomposite as a promising biocidal agent against methicillin-resistant Staphylococcus aureus. Int. J. Nanomed. 2015, 10, 6847-6861. [CrossRef]

35. Kanchanapally, R.; Nellore, B.P.V.; Sinha, S.S.; Pedraza, F.; Jones, S.J.; Pramanik, A.; Chavva, S.R.; Tchounwou, C.; Shi, Y.; Vangara, A.; et al. Antimicrobial peptide-conjugated graphene oxide membrane for efficient removal and effective killing of multiple drug resistant bacteria. RSC Adv. 2015, 5, 18881-18887. [CrossRef] [PubMed]

36. Stout, D.A.; Basu, B.; Webster, T.J. Poly(lactic-co-glycolic acid): Carbon nanofiber composites for myocardial tissue engineering applications. Acta Biomater. 2011, 7, 3101-3112. [CrossRef] [PubMed]

37. Llorens-Gámez, M.; Serrano-Aroca, Á. Low-Cost Advanced Hydrogels of Calcium Alginate/Carbon Nanofibers with Enhanced Water Diffusion and Compression Properties. Polymers 2018, 10, 405. [CrossRef] [PubMed]

38. Morgan, P. Carbon Fibers and Their Composites, 1st ed.; Taylor \& Francis: Boca Raton, FL, USA, 2005.

39. Gardea, F.; Naraghi, M.; Lagoudas, D. Effect of thermal interface on heat flow in carbon nanofiber composites. ACS Appl. Mater. Interfaces 2014, 6, 1061-1072. [CrossRef] [PubMed]

40. Serrano-Aroca, Á.; Ruiz-Pividal, J.F.; Llorens-Gámez, M. Enhancement of water diffusion and compression performance of crosslinked alginate with a minuscule amount of graphene oxide. Sci. Rep. 2017, 7, 11684. [CrossRef] [PubMed]

41. Serrano-Aroca, Á.; Deb, S. Synthesis of irregular graphene oxide tubes using green chemistry and their potential use as reinforcement materials for biomedical applications. PLoS ONE 2017, 12, e0185235. [CrossRef] [PubMed]

42. Serrano-Aroca, Á.; Iskandar, L.; Deb, S. Green synthetic routes to alginate-graphene oxide composite hydrogels with enhanced physical properties for bioengineering applications. Eur. Polym. J. 2018, 103, 198-206. [CrossRef]

43. Sánchez-Correa, F.; Vidaurre-Agut, C.; Serrano-Aroca, A.; Campillo-Fernández, A.J. Poly(2-hydroxyethyl acrylate) hydrogels reinforced with graphene oxide: Remarkable improvement of water diffusion and mechanical properties. J. Appl. Polym. Sci. 2018, 135, 46158. [CrossRef]

44. Frígols, B.; Martí, M.; Salesa, B.; Hernández-Oliver, C.; Aarstad, O.; Ulset, A.S.T.; Sætrom, G.I.; Aachmann, F.L.; Serrano-Aroca, Á. Graphene oxide in zinc alginate films: Antibacterial activity, cytotoxicity, zinc release, water sorption/diffusion, wettability and opacity. PLoS ONE 2019, 14, e0212819. [CrossRef] [PubMed]

45. Zhao, E.; Chen, Y.; Wang, H.; Chen, S.; Lam, J.W.Y.; Leung, C.W.T.; Hong, Y.; Tang, B.Z. Light-enhanced bacterial killing and wash-free imaging based on AIE fluorogen. ACS Appl. Mater. Interfaces 2015, 7, 7180-7188. [CrossRef] [PubMed]

46. Xie, X.; Mao, C.; Liu, X.; Zhang, Y.; Cui, Z.; Yang, X.; Yeung, K.W.K.; Pan, H.; Chu, P.K.; Wu, S. Synergistic Bacteria Killing through Photodynamic and Physical Actions of Graphene Oxide/Ag/Collagen Coating. ACS Appl. Mater. Interfaces 2017, 9, 26417-26428. [CrossRef] [PubMed] 
47. Li, X.Z.; Nikaido, H.; Williams, K.E. Silver-resistant mutants of Escherichia coli display active efflux of $\mathrm{Ag}^{+}$ and are deficient in porins. J. Bacteriol. 1997, 179, 6127-6132. [CrossRef] [PubMed]

48. Chong, Y.; Ge, C.; Fang, G.; Wu, R.; Zhang, H.; Chai, Z.; Chen, C.; Yin, J.J. Light-Enhanced Antibacterial Activity of Graphene Oxide, Mainly via Accelerated Electron Transfer. Environ. Sci. Technol. 2017, 51, 10154-10161. [CrossRef] [PubMed]

49. Yeh, N.G.; Wu, C.H.; Cheng, T.C. Light-emitting diodes-Their potential in biomedical applications. Renew. Sustain. Energy Rev. 2010, 14, 2161-2166. [CrossRef]

50. Monteiro, N.; Thrivikraman, G.; Athirasala, A.; Tahayeri, A.; França, C.M.; Ferracane, J.L.; Bertassoni, L.E. Photopolymerization of cell-laden gelatin methacryloyl hydrogels using a dental curing light for regenerative dentistry. Dent. Mater. 2018, 34, 389-399. [CrossRef] [PubMed]

51. Lee, J.Y.H.; Monk, I.R.; Gonçalves da Silva, A.; Seemann, T.; Chua, K.Y.L.; Kearns, A.; Hill, R.; Woodford, N.; Bartels, M.D.; Strommenger, B.; et al. Global spread of three multidrug-resistant lineages of Staphylococcus epidermidis. Nat. Microbiol. 2018, 3, 1175-1185. [CrossRef] [PubMed]

52. Wade, K.C.; Benjamin, D.K. Clinical Pharmacology of Anti-Infective Drugs. In Infectious Diseases of the Fetus and Newborn Infant; Elsevier: Philadelphia, PA, USA, 2011; pp. 1160-1211.

53. Lakhundi, S.; Zhang, K. Methicillin-Resistant Staphylococcus aureus: Molecular Characterization, Evolution, and Epidemiology. Clin. Microbiol. Rev. 2018, 31, e00020-18. [CrossRef] [PubMed]

54. Chessa, D.; Ganau, G.; Spiga, L.; Bulla, A.; Mazzarello, V.; Campus, G.V.; Rubino, S. Staphylococcus aureus and Staphylococcus epidermidis Virulence Strains as Causative Agents of Persistent Infections in Breast Implants. PLoS ONE 2016, 11, e0146668. [CrossRef]

55. Speziale, P.; Geoghegan, J.A. Biofilm Formation by Staphylococci and Streptococci: Structural, Functional and Regulatory Aspects and Implications for Pathogenesis; Frontiers Media SA: Lausanne, Switzerland, 2015.

56. Zefirov, Y.V.; Zorky, P.M. New applications of van der Waals radii in chemistry. Russ. Chem. Rev. 1995, 64, 415. [CrossRef]

57. Zhao, J.; Liu, L.; Li, F. Graphene Oxide: Physics and Applications; Springer: London, UK, 2014.

58. Liu, Y.; Pan, C.; Wang, J. Raman spectra of carbon nanotubes and nanofibers prepared by ethanol flames. J. Mater. Sci. 2004, 39, 1091-1094. [CrossRef]

59. Ferrari, A.C.; Robertson, J. Interpretation of Raman spectra of disordered and amorphous carbon. Phys. Rev. B 2000, 61, 14095-14107. [CrossRef]

60. Cançado, L.G.; Jorio, A.; Ferreira, E.H.M.; Stavale, F.; Achete, C.A.; Capaz, R.B.; Moutinho, M.V.O.; Lombardo, A.; Kulmala, T.S.; Ferrari, A.C. Quantifying defects in graphene via Raman spectroscopy at different excitation energies. Nano Lett. 2011, 11, 3190-3196. [CrossRef] [PubMed]

61. Li, Y.; Du, Q.; Liu, T.; Peng, X.; Wang, J.; Sun, J.; Wang, Y.; Wu, S.; Wang, Z.; Xia, Y.; et al. Comparative study of methylene blue dye adsorption onto activated carbon, graphene oxide, and carbon nanotubes. Chem. Eng. Res. Des. 2013, 91, 361-368. [CrossRef]

62. Christensen, G.D.; Bisno, A.L.; Parisi, J.T.; McLaughlin, B.; Hester, M.G.; Luther, R.W. Nosocomial septicemia due to multiply antibiotic-resistant Staphylococcus epidermidis. Ann. Int. Med. 1982, 96, 1-10. [CrossRef] [PubMed]

63. Gill, S.R.; Fouts, D.E.; Archer, G.L.; Mongodin, E.F.; DeBoy, R.T.; Ravel, J.; Paulsen, I.T.; Kolonay, J.F.; Brinkac, L.; Beanan, M.; et al. Insights on evolution of virulence and resistance from the complete genome analysis of an early methicillin-resistant Staphylococcus aureus strain and a biofilm-producing methicillin-resistant Staphylococcus epidermidis strain. J. Bacteriol. 2005, 187, 2426-2438. [CrossRef] [PubMed]

64. Martí, M.; Frígols, B.; Serrano-Aroca, Á. Antimicrobial Characterization of Advanced Materials for Bioengineering Applications. J. Vis. Exp. 2018, 138, e57710. [CrossRef]

65. Yakoob, J.; Naz, S.; Awan, S.; Abbas, Z.; Jafri, W.; Hamid, S.; Jafri, F.; Usman, M.W. Comparison of Antimicrobial Activity of Zinc Chloride and Bismuth Subsalicylate Against Clinical Isolates of Helicobacter pylori. Microb. Drug Resist. 2013, 20, 305-309. [CrossRef]

66. Straccia, M.C.; Romano, I.; Oliva, A.; Santagata, G.; Laurienzo, P. Crosslinker effects on functional properties of alginate/N-succinylchitosan based hydrogels. Carbohydr. Polym. 2014, 108, 321-330. [CrossRef]

(C) 2019 by the authors. Licensee MDPI, Basel, Switzerland. This article is an open access article distributed under the terms and conditions of the Creative Commons Attribution (CC BY) license (http://creativecommons.org/licenses/by/4.0/). 